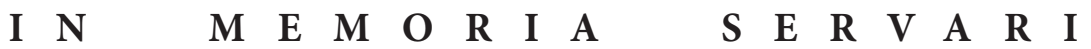

Zeszyty Prawnicze

20.2 / 2020, s. 341-342

DOI 10.21697/zp.2020.20.2.19

\section{PODZIĘKOWANIE ZA WKŁAD W ROZWÓJ WIKTYMOLOGII}

23 maja 2017 r. w PAN odbyła się konferencja „Wiktymologia - wczoraj i dziš" poświęcona Profesor Ewie Bieńkowskiej. Jej wieloletnia współpracownica Lidia Mazowiecka tak jej dziękowała za wkład w rozwój wiktymologii:

Droga Ewo, Kochana Ewo, Mój Mentorze, Nasza Koleżanko i Przyjaciółko, Przyjaciółko Ofiar Przestępstw,

Pierwszy raz spotkałam się z Tobą dwadzieścia lat temu, w 1997 r., właśnie tutaj w PAN,

Tak jak dzisiaj spotkałyśmy się na pierwszym piętrze, w takim ciemnym, bardzo wąskim i głośnym pokoju Instytutu Nauk Prawnych,

Pracowałam wtedy w Ministerstwie Sprawiedliwości i zaczynałam zajmować się ofiarami przestępstw. Szukałam ludzi znających tę problematykę.

Pamiętam entuzjazm z jakim przyjęłaś moją propozycję współpracy,

Pamiętam, jak ucieszyłam się, że poznałam taką fajną osobę,

Od tamtego momentu współpracuję z Tobą w instytucjach rządowych i pozarządowych, przede wszystkim w Ministerstwie Sprawiedliwości, Prokuraturze Generalnej, Ogólnopolskim Forum na Rzecz Ofiar Przestępstw, razem piszemy.

Dużo Ci zawdzięczam, dzięki Tobie stałam się lepszym prokuratorem, bo wrażliwym na krzywdę i cierpienie człowieka, lepszym człowiekiem i lepszym mediatorem, zaraziłaś mnie wiarą $\mathrm{w}$ dobrą mediację, sama stałam się mediatorką i dołączyłam się do Twojej wręcz wojny prawnej o odpowiednie rozwiązania w mediacji. 
Dziękuje Ci za czasami codzienne uwagi dotyczące mojej pracy, za wielogodzinne dyskusje nad problemami ofiar przestępstw, za to że stawiasz mnie do pionu, gdy zbyt pochopnie analizuję nowe rozwiązania na rzecz ofiar, przypominasz mi, że na pierwszym miejscu jest zawsze godność drugiego człowieka.

Twoje zaangażowanie i merytoryczne wsparcie w pracach na rzecz ofiar przestępstw wpłynęło na poprawienie ich sytuacji w Polsce, doprowadziło do tego, że osoby, które na co dzień pracują z ofiarami przestępstw są bardziej profesjonalne i mają więcej empatii.

Cenimy Ciebie nie tylko za olbrzymią wiedzę prawniczą, ale za to że jesteś otwarta, tolerancyjna, wyważona, o bardzo wysokiej kulturze osobistej, rzucająca wszystko, gdy potrzeba pomóc ofierze przestępstwa,

Jesteś też niezmiernie dzielna w przezwyciężaniu swoich codziennych trudności życiowych i dolegliwości zdrowotnych. Nie znam takiej drugiej osoby, która tak wiele doświadczyła w życiu i potrafiła się z tym uporać.

Książka, którą dzisiaj Ci wręczamy jest o ofiarach przestępstw i mediacji, napisała ją grupa Twoich przyjaciół i znajomych, Ci którzy nie mogli z różnych powodów napisać dołączyli swoje gratulacje. Jest tych osób naprawdę dużo, reprezentują różne środowiska: naukowców, wydawców, sędziów, prokuratorów, mediatorów, funkcjonariuszy policji. Mamy nadzieję, że spodoba Ci się. Mamy też nadzieję, że tak jak lubisz, będzie pomocna w pracy.

Ewa wiedziała, że jest bardzo chora. Zmarła 14 marca 2018 r. Marzyła, żeby zdążyć przed śmiercią napisać kompleksową książkę o ofiarach. I napisała wspaniała książkę „Wiktymologia” wydaną w 2018 r., niedługo po jej śmierci, którą wszystkim polecam.

Lidia Mazowiecka 